\title{
U.S.-MONGOLIAN RELATIONS: TWO YEARS OF PROGRESS
}

\section{By Alphonse La Porta and Andrew J. Critchfield}

Two years ago, an article in this journal entitled, "The Future is now," presented prospects for expansion of U.S.-Mongolian relations. The article identified several goals for Mongolia and the United States and highlighted the promise that the future held for the two countries. It is a pleasure to report that, in fact, many of the goals outlined then have been achieved or are being accomplished. The fabric of U.S.-Mongolian relations has been woven tightly during the past few years and continues to strengthen. In effect, we are experiencing the future projected in the article two years ago.

One stated goal for U.S.-Mongolian relations was to encourage high-ranking U.S. civilian and military officials to visit Mongolia. U.S. Secretary of State Madeleine Albright visited Mongolia in May 1998. Since then, other U.S. officials have also visited, including Under Secretary of State for Political Affairs Thomas Pickering, Under Secretary of Defense for Policy Walter Slocomb, Counselor of the Department of Commerce Jan Kalicki, and Commander of the Pacific Command Admiral Dennis Blair. Most recently, Supreme Court Justice Sandra Day O'Connor visited Mongolia in September, 2000.

These visits by U.S. officials, and reciprocal visits to the United States by Mongolia's Prime Minister, Foreign Minister, and other Mongolian officials, have enabled political leaders of both nations to know each other better and have given U.S. decision-makers a first-hand look at Mongolian conditions. The visits have fostered a strong foundation for the political relationship, economic development assistance policies, the military-to-military relationship, and commercial policies. They also have helped build a foundation for an as-yet unfulfilled goal: a visit to Mongolia by a U.S. President or Vice President.

Many U.S.-Mongolian projects and proposals which were in the planning stage two years ago are now being implemented, demonstrating the great progress that has been achieved in the bilateral relationship. For example, new United States Agency for International Development (USAID) programs are running smoothly and benefiting Mongolia's rural development in tangible ways. These

-ALFONSE LA PORTA is the former U.S. Ambassador to Mongolia

- A.J. CRITCHFIELD /M.S.Ithaca College, 1997/ resides in Washington, DC, Where he is a Howard University Sasakawa Fellow 
include the Farmer-to-Farmer Program that strengthens the ability of herders to make sound economic decisions and builds institutional capacities in enterprise and market development. The program assists in improving the breed of Mongolia's cashmere goats and introduces new farming technologies and management methods. Another USAID project, the Gobi Regional Economic Growth Initiative, uses its own newspaper, the Gobi Business News, and a local radio station to provide herders with commercial news and commentary that will integrate their enterprises more fully with their markets and increase for them the benefits of a free-market system. USAID also has established an innovative, non-bank financial institution which provides capital to herders for modernizing and diversifying their enterprises.

USAID's programs respond to the Mongolian Government's request for economic policy expertise to bring the benefits of the free-market system to its citizens. For instance, since 1995 the DAI Economic Policy Support Program has been helping the Mongolian Government provide businessmen and citizens with a renovated, up-to-date banking system for their business and personal needs, as well as providing advice on sound macro-economic policies. The Barents Group is assisting the Government in its privatization of state property and is supporting public education efforts to help Mongolian citizens understand the concept and process of privatization. The pension reform program, developed with USAID assistance, was approved by the Mongolian Parliament last year. USAID is funding A Country Competitiveness Exercise which will help Mongolia's private and public sector leaders identify potential economic growth areas in this time of globalization.

In areas outside the economic sphere, the U.S. has made its expertise available to Mongolia. Mongolian and American legal experts-supported by USAID assistance-worked together on USAID's Rule of Law program and drafted a strategic plan for the reform of the Mongolian judicial system. This plan, approved by Parliament in April 2000, can serve as a framework around which the Mongolian Government will be better prepared to coordinate international donor support while eliminating redundancy and increasing productivity. Mongolia can enjoy a legal system that promotes political freedoms and economic progress.

U.S. scientific cooperation with the Mongolian Academy of Sciences has grown. Mongolian scientists work with the U.S. Geological Survey, NASA, and the U.S. Air Force, among others. A new agreement with the U.S.-Asia Environment Program (US-AEP) will focus on urban planning, zoning, and financial management. 
The Peace Corps program continues to grow. Two years ago about 50 American volunteers served in Mongolia; by the end of 2000 over 90 volunteers will be serving throughout the country. These volunteers provide a glimpse, particularly in the countryside, of American values and personal energy. They also are a major U.S. Government resource supporting English language study, thereby increasing Mongolia's ability to interact effectively with the global community.

U.S. humanitarian assistance to Mongolia has increased. In fact, the continued transfers of U.S. development and humanitarian assistance exceed the $\$ 12$ million per year level that was set for the USAID country program. These additional expenditures include \$2-3 million in wheat assistance each year; during Fiscal Year 2000, between \$3.5-4.0 million of wheat assistance was donated for winter disaster relief. Annually, the U.S. provides Mongolia over \$2.5 million in military humanitarian assistance. U.S.-funded educational programs in Mongolia bring the total resource donation to well over $\$ 16$ million per year.

U.S.-Mongolian defense cooperation for military education and training has grown with the implementation of new programs, amounting to over $\$ 2.5$ million per year. The U.S. and Mongolia have agreed to cooperate further to modernize the Mongolian Armed Forces for participation in international peacekeeping. This year, the U.S. will provide an additional $\$ 350,000$ in assistance for peacekeeping training, as well as funds and training for the Mongolian Elite Battalion to participate in the Central Asia Battalion (CENTRASBAT) peacekeeping training exercise. As Mongolia establishes itself as a regular partner in peacekeeping, it will benefit from a fresh identity as a country that is integrating itself with the world community in a constructive manner.

The U.S. and Mongolia have agreed to carry out further bilateral consultations on the role of U.S. assistance in helping Mongolia maintain and improve its defense capabilities, such as border communications. Requested funding for border communications equipment is pending approval in the U.S. Congress. Improved defense capabilities will help Mongolia balance its bilateral relationships with its two large neighbors and its relationships with other countries in the region.

The U.S. looks forward to significant growth in regional law enforcement cooperation and coordination activities to combat transnational problems such as narcotics, smuggling, counterfeiting and money laundering, and the illegal movement of people. U.S. Government agencies will provide training in border enforcement, transnational criminal investigations, and forensics as these is- 
sues become more important in the bilateral relationship and in Mongolia's relationships with other nations.

With realization of many concrete bilateral goals, the relationship shared by the U.S. and Mongolia has moved beyond the rhetorical "third neighbor" approach first cited by Secretary of State James Baker during his 1991 visit to Mongolia. America is doing much to introduce Mongolia to its neighbors in the community of democracies. As Mongolia becomes more fully intertwined within its community through political, economic, and cultural ties, its identity as a contributing member will grow, and its future will be much more secure.

Senior officials from the Mongolian Ministry of Foreign Affairs and the U.S. Department of State meet annually to discuss regional and global issues. In May 200Q, the latest in a series of such bilateral consultations was held in Bangkok, Thailand. The discussions addressed a number of topics, including relations with Mongolia's neighbors, China and Russia, as well as the Korean Peninsula and other regional concerns. These discussions highlighted views on regional issues shared by the two governments, confirming that U.S.-Mongolian relations are based upon more than the transfer of resources.

First, both the U.S. and Mongolia strongly support engagement with Russia and China in the ASEAN Regional Forum (ARF). Second, both nations advocate rapprochement between North and South Korea and the other processes that have been implemented to help North Korea become a better regional citizen. Third, both the U.S. and Mongolia fully agree that a greater emphasis on preventive diplomacy in Northeast Asia is necessary. Fourth, both countries look forward to a strong, stable, prosperous, and moderate China as a positive force in regional stability. Fifth, both countries recognize a need for dialogue with China on a full range of security, political, and economic issues, including democracy and human rights, missile technology and nonproliferation, and regional law enforcement. Mongolia and the U.S. share a common interest in issues related to China's governance of Tibet and share a common perception on religious freedom. Sixth, the U.S. and Mongolia both understand the importance of maintaining continued dialogue with Russia on issues such as NATO expansion, human rights, nuclear arms reductions, and nuclear missile defense.

While the past two years of progress have brought greater cooperation and mutual understanding, it is also necessary to recognize that the immediate future holds three areas of concern for U.S.-Mongolian relations.

First, there is concern that external assistance is not being used efficiently in Mongolia and thus, that the nation will become dependent upon aid. Political 
stalemate has prevented Parliament from approving important economic and social reforms in the past two years, contributing to donor skepticism and donor fatigue. A related concern among donor countries is that Mongolia may relax its economic reforms and return to policies of state control of production and outdated socialist ideas, rather than decide how Mongolia can compete in global economy. For example, Mongolia desperately needs a modern infrastructure. The energy system and industrial infrastructure are 30-50 years old and inadequate for Mongolia to compete in global commerce. This kind of problem requires realistic, objective analysis and effective policy-making.

Second, there is concern in the U.S. over the future direction of Mongolia's leadership. Political stalemate of the past two years, with needed legislative action frozen by partisan intransigence in Parliament, necessitates reexamination of Mongolia's consensus for governance. This issue needs continued discussion with leaders of the newly elected Government. The debate on governance includes two important issues-the powers of the presidency and the degree to which Mongolia has or should move towards a presidential form of government; and the proper role and functioning of the Constitutional Court. Further, the role of the Constitution itself as the basis for governance must be examined. Some of these issues will be considered under the USAID Rule of Law program.

The third also of immediate concern for U.S.-Mongolian relations is the economic and political policies of the new Government. There arc some concerns that the new Government may adopt regressive political and economic policies that can undermine the foundations for future U.S. cooperation. The democratic credentials of the Mongolian People's Revolutionary Party (MPRP) were established when the Mongolian people clearly supported it at the polls. The U.S. had a strong interest in seeing that the elections of July 2000 were free and fair. The International Republican Institute, IRI, worked with the Election Commission on a number of initiatives. The IRI posted observers in Ulaanbaatar and in several aimags to observe the actual conduct of the election. They concluded that the elections were free and fair, although they witnessed problems that should be addressed before local elections in the fall of 2000.

The U.S. will deal with the new Government on the same basis as the former coalition government. The policies of the new Government will influence U.S. policy-making, just as the policies of the former coalition had an impact on the formulation of U.S. policies during the past four years. The policies of the ruling MPRP and their implementation remain to be seen. 
However, there were some items on the MPRP election platform that were clearly different from the development strategy that was adopted by the government when the MPRP last led the Government in 1992-96. For example, some MPRP leaders have said that the Central Bank should not be independent. The MPRP platform also indicated that the Government would intervene in exchange rates and interest rates. Governmental intervention in these areas and other policies will likely bring conflict with the World Bank, IMF, and other donors. The International donor's consultative group meeting, now scheduled for November 30-December 1, 2000, will include an intensive examination of the economic policies of Mongolia's new Government.

The U.S. seeks to work with the new Government and hopes it will seek consensus in the Parliament and in the community at large. The U.S. would like to see a Mongolian Government that promotes civil society and redefines national attitudes on key issues such as corruption. There must be resistance to any return of authoritarianism. The U.S. favors development of parliamentary, multi-party democracy in Mongolia, and the worldwide democratic community joins the U.S. in this wish for Mongolia and its people.

U.S.-Mongolian relations require the two countries to nurture their relationship in order to effectively promote shared interests. The U.S. and Mongolia have paid particular attention to this concept in the past two years, and as a result, substantial progress has been made. The U.S. sees a more stable, more prosperous Mongolia which supports regional stability and prosperity, a Mongolia dealing seriously with judicial reform, democratization, economic liberalization, privatization, and development of an expansive foreign policy which links it with the region and the world.

In turn, we hope Mongolia sees the U.S. as a reliable partner, a country with much to offer in terms of assistance and support as Mongolia continues it's political, economic and social reforms. If both nations continue to nurture the relationship with respect for mutual interests and values, the bilateral relationship will continue to grow.

With cooperation and continued engagement, U.S.-Mongolian relations will continue to resemble a tightly woven fabric. The fulfillment of many more promises and opportunities await us. 